\title{
Article \\ Use of Lentinan and Fluopimomide to Control Cotton Seedling Damping-Off Disease Caused by Rhizoctonia solani
}

\author{
Shoumin Sun ${ }^{1,+}$, Haohao Yan ${ }^{1,+} \mathbb{D}$, Gang Chen ${ }^{1}$, Shuai Yang ${ }^{1}$, Jie Wang ${ }^{2}$, Yuanxue Yang ${ }^{3}$ \\ and Hongyan Wang $1, *$ D
}

Citation: Sun, S.; Yan, H.; Chen, G.; Yang, S.; Wang, J.; Yang, Y.; Wang, H. Use of Lentinan and Fluopimomide to Control Cotton Seedling Damping-Off Disease Caused by Rhizoctonia solani. Agriculture 2022, 12, 75. https://doi.org/10.3390/ agriculture12010075

Academic Editor: Renata Bažok

Received: 3 December 2021

Accepted: 4 January 2022

Published: 6 January 2022

Publisher's Note: MDPI stays neutral with regard to jurisdictional claims in published maps and institutional affiliations.

Copyright: (C) 2022 by the authors. Licensee MDPI, Basel, Switzerland. This article is an open access article distributed under the terms and conditions of the Creative Commons Attribution (CC BY) license (https:// creativecommons.org/licenses/by/ $4.0 /)$.
1 Department of Plant Protection, Shandong Agricultural University, Tai'an 271018, China; ssm1638946412@163.com (S.S.); 17863801132@163.com (H.Y.); cg15052715639@163.com (G.C.); sdauyys@163.com (S.Y.)

2 Key Laboratory of Tobacco Pest Monitoring Controlling \& Integrated Management, Tobacco Research Institute of Chinese Academy of Agricultural Sciences, Qingdao 266101, China; wangjie@caas.cn

3 Institute of Industrial Crops, Shandong Academy of Agricultural Sciences, Jinan 250100, China; yangyuanxue1989@163.com

* Correspondence: hongyanwang@sdau.edu.cn

+ These authors contributed equally to this work.

\begin{abstract}
Lentinan (LNT) is a natural and functional polysaccharide isolated from Lentinus edodes fruiting bodies, which functions in stimulating the plant immune response, improving plant disease resistance and regulating plant growth. This study explores the use of LNT as a plant growth regulator and attractant in cotton production. After treatment with LNT, the content of malondialdehyde (MDA) in cotton seeds decreased, whereas the activities of polyphenol oxidase (PPO), superoxide dismutase (SOD) and peroxidase (POD) in leaves increased significantly. LNT also promoted the growth and development of cotton plants and significantly reduced the incidence of cotton dampingoff disease. The relative expression of salicylic acid pathway-related genes in cotton also increased significantly. The prevention mechanism of fluopimomide was also evaluated, and the result showed lower $\mathrm{EC}_{50}$ values and was effective in controlling cotton seedling disease caused by Rhizoctonia solani in both greenhouse experiments and field trials. The use of LNT and fluopimomide in controlling cotton seedling damping-off disease showed a synergistic effect in field trials. These results will provide a new insight into the agricultural application of LNT as a biological fungicide in the field of biological controls.
\end{abstract}

Keywords: cotton damping-off disease; lentinan; Rhizoctonia solani; environmentally friendly biopesticide; defensive enzymes

\section{Introduction}

Cotton (Gossypium hirsutum L.) is a natural fiber crop widely grown around the world [1,2]. However, cotton damping-off disease caused by Rhizoctonia solani, is an important soil-borne and seedling disease $[3,4]$ which affects cotton production and agricultural economy [5]. Pathogenic isolates of this fungus can infect at least 188 kinds of higher plants, including vegetables, forest trees, cereals and ornamental plants [6]. The species can be categorized into two groups: anastomosis groups (AG) and intraspecific groups (ISGs) of R. solani species. Many AGs have been characterized $[7,8]$ and the primary disease-causing $R$. solani species of cotton belongs to the AG-4 group.

Lentinan (LNT) is a new type of natural functional polysaccharide isolated from Lentinus edodes fruiting body that can reduce damage caused by oxygen free radicals to organelles and has a good inhibitory effect on plant diseases [9]. Lentinan could promote the elongation of the roots but has no effect on dry weight since the concentration of lentinan in plant is low [10]. LNT primary structure is a $\beta$-1,3-glucan (Figure 1) [11], which is a major component of cell walls of bacteria, fungi, seaweeds and plants. The biological 
activity of lentinan is closely related to its structure [12]. These properties depend on the primary structure of the glucan, such as the degree of polymerization and branching [13]. It has been reported that LNT exists as a right-handed triple-helical conformation in an aqueous solution [14]. Trotel-Aziz et al. found that $\beta$-1,3-glucan has a good controlling effect on grape powdery mildew and grape downy mildew [15]. Ménard et al. also found that $\beta$-1,3-glucan sulfate can induce tobacco disease resistance [16]. In recent years, a substantial amount of evidence has shown that the plant's inherent immunity plays a role in R. solani infection [17]. Moreover, many resistance proteins against $R$. solani infection have been identified, such as enzymes in the glycolytic pathway, chitinase and glutathione peroxidase [18].

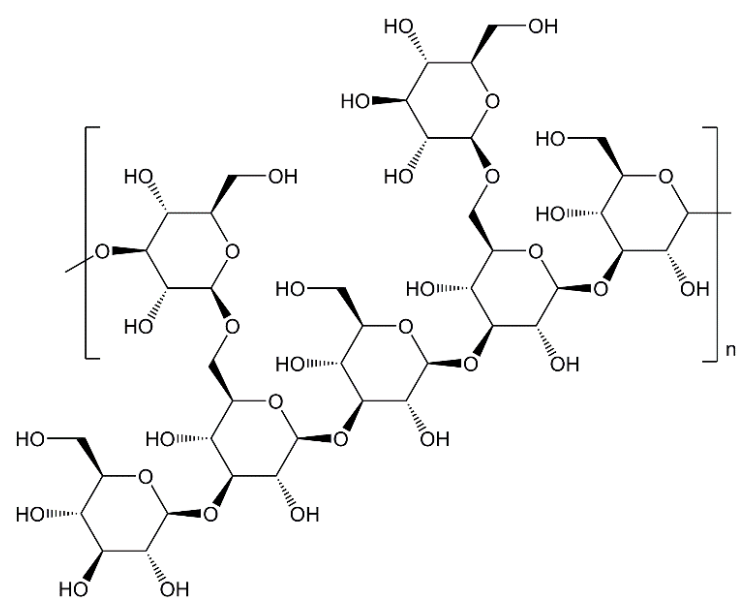

Figure 1. Three-dimensional chemical structure of polysaccharides-proteoglycan repeating unitsextracted from Lentinus edodes. The major polysaccharides identified in Lentinan bodies had a $\beta$-(13)-linked D-glucopyranosyl residue as the main chain and (1-6) glucan residue on the side chain.

Furthermore, fluopimomide, ( $N$-(3-chloro-5-trifluoromethyl-pyridin-2-ylmethyl-2,3,5,6tetrafluoro-4-methoxy-benzamide)), a new fungicide released by Shandong Sino-Agri Union Biotechnology Co. Ltd., Jinan, China [19], can effectively control diseases caused by oomycete pathogens [20], such as Meloidogyne incognita in tomato [21] and cucumber [22].

The use of chemical fungicides is still a major control measure against plant pathogens [21], which can negatively impact human health and the environment [23]. Alternatively, biopesticides obtained from diverse natural plants and microorganisms [24], are less hazardous to the environment as compared with chemical pesticides [25]. In recent years, there has been an increase in the adoption and application of biological controls, such as the application of biopesticides by farmers in controlling pest and plant diseases, thereby creating a hot spot for worldwide research into biopesticides [26,27].

In this research, we conducted in vivo toxicity experiments of seven fungicides against $R$. solani mycelial growth on cotton plants in the greenhouse and open field. This was carried out to assess the potential effect of LNT and fluopimomide on R. solani and the possible mechanisms of action. Together, this paper will provide a basis for the scientific and reasonable application of LNT and fluopimomide in the prevention and control of cotton diseases. It can also provide a theoretical and practical basis for the development, evaluation and utilization of new pesticides. Collectively, this study will significantly strengthen disease prevention and control techniques against cotton seedling diseases through the efficient and rational use of pesticides. This will enhance cotton production as well as quality of cotton.

\section{Materials and Methods}

\subsection{Fungal Strains and Fungicides Preparation}

Fungal strains AG-2 (standard strain, only used for in vivo toxicity test), AG-4 (standard strain, used in all tests in this study), and LQ-M (it belongs to AGs that were collected 
from the field, only used for in vivo toxicity test) were provided by the Institute of Plant Protection, Hebei Academy of Agricultural and Forestry Sciences. All chemicals and analytical reagents of the experiment were purchased from Nanjing Vazyme Biotech Co., Ltd. (Nanjing, China).

Hexaconazole (CAS: 79983-71-4, 96.7\% purity), pyraclostrobin (CAS: 175013-18-0, 98.0\% purity), fludioxonil (CAS: 131341-86-1, 98.0\% purity), carbendazim (CAS: 10605-21-7, 98.0\% purity), difenoconazole (CAS: $119446-68-3,97 \%$ purity) and fluopimomide (CAS: 1309859-39-9, 98.0\% purity) were provided from College of Plant Protection, Key Laboratory of Pesticide Toxicology and Application Technique, Shandong Agricultural University, Tai'an, Shandong, China. Extraction and purification of LNT were performed according to Zhang et al. [9]. Carbendazim and other fungicides stock solutions $\left(1 \times 10^{4} \mathrm{mg} \mathrm{L}^{-1}\right)$ were prepared with $3 \%$ hydrochloric acid and acetone, respectively, and stored at $4{ }^{\circ} \mathrm{C}$.

\subsection{Field Investigation of Main Cotton Seedling Diseases}

According to the cotton planting situation in Shandong Province, China, the five-point sampling method was adopted in the six major cotton growing areas of Dezhou, Liaocheng, Dongying, Binzhou, Heze and Jining. At each point, 50 cotton seedlings were randomly selected to investigate the occurrence of diseases at the cotton seedling stage, and the incidence rate was calculated. The classification standards are as follows [28]:

1. Grade 0: No spots at the base of the stem;

2. Grade 1: The diseased spots at the base of the stem occupy less than $1 / 3$ of the entire stem circumference;

3. Grade 2: The diseased spots at the base of the stem account for $1 / 3-1 / 2$ of the entire stem circumference;

4. Grade 3: The diseased spots at the base of the stem occupy $1 / 2-3 / 4$ of the entire stem circumference;

5. Grade 4: The diseased spots at the base of the stem account for $3 / 4$ or more of the entire stem circumference.

The disease index (DI) and control effect (CE) was calculated according to the following formula: $\mathrm{DI}=(\Sigma$ (diseased leaf number of every grade $\times$ corresponding grade number) $) /$ total (leaf number investigated $\times$ the highest grade number $) \times 100 ; \mathrm{CE}(\%)=((\mathrm{DI}$ of the control - DI of the treatment)/DI of the control) $\times 100$.

\subsection{In Vivo Toxicity Experiments}

The purpose of the mycelium growth rate method was to determine pesticide sensitivity [2]. Inoculate fungal cake (diameter $=7 \mathrm{~mm}$ ) on PDA medium plates containing different concentrations of each pesticide. Meanwhile, sterile distilled water was used as a control, with three repetitions for each treatment, and culture in the dark at $25^{\circ} \mathrm{C}$. When the control mycelium grows above $70 \mathrm{~mm}$, use the cross method to measure the colony diameter comparison of control containing medicaments. A regression equation, the inhibition concentration $\mathrm{EC}_{50}$ and a correlation coefficient were used to evaluate the bacteriostatic effect according to the $\mathrm{EC}_{50}$ size. The final active ingredient concentration of each agent was shown in Table 1.

Table 1. Seven final active ingredients of the pesticide of fungicide.

\begin{tabular}{cc}
\hline Fungicide & Active Ingredient Concentration (mg/L) \\
\hline fludioxonil & $0.003,0.006,0.012,0.025,0.050,0.100,0.200$ \\
carbendazim & $3.125,6.250,12.500,25.000,50.000,100.000$ \\
difenoconazole & $0.313,0.625,1.250,2.500,5.000,10.000$ \\
pyraclostrobin & $0.013,0.025,0.050,0.100,0.200,0.400$ \\
hexaconazole & $0.013,0.025,0.050,0.100,0.200,0.400$ \\
fluopimomide & $0.031,0.063,0.125,0.250,0.500,1.000,2.000$. \\
lentinan & $6.250,12.500,25.000,50.000,100.000,200.000$ \\
\hline
\end{tabular}




\subsection{Seed Coating Formulation Screening and Coating Treatment}

The preparation of seed coating agent was carried out according to Marín et al. [29], by using the wet sand processing superfine grinding method. Pesticides with and without surfactants were prepared by dispersing the biopolymers $(2 \% w / v)$ in deionized water. The rotor-stator homogenizer makes the active ingredients of pesticides form a stable dispersion system. Then, other additives were added (including the plant growth regulators, filmforming auxiliaries, etc.) into the aqueous solution in a certain proportion, and stirring was continued at $25{ }^{\circ} \mathrm{C}$ for 4 to $5 \mathrm{~h}$ until completely dissolved. The CIPAC method was used to determine the stability, which fulfilled the requirements of pesticide preparation well.

Based on determining the toxicity of a single agent, we selected fungicides and plant antagonists for mixing and performed a combined toxicity determination of LNT and fluopimomide. The mixture was compounded according to 1:10, 1:20, 1:30, 1:40, 1:50 and the actual $\mathrm{EC}_{50}$ value of the mixture of different proportions was determined. The test and calculation methods were the same as the single-agent indoor toxicity determination. The synergic ratio (SR) of the mixture was calculated to evaluate the synergistic effect of different proportions. The ratio with the highest synergistic coefficient was chosen: 50\% fluopimomide WG, 2\% LNT AS, and L311 and L811 film formers were used to prepare seed coatings. The seeds and seed coating agent were used according to the dosage, and dried in a cool place for later use.

$$
\begin{aligned}
& \mathrm{EC}_{50}(\mathrm{th})=(\mathrm{a}+\mathrm{b}) /\left(\mathrm{a} / \mathrm{EC}_{50} \mathrm{~A}+\mathrm{b} / \mathrm{EC}_{50} \mathrm{~B}\right) \\
& \text { Synergic ratio }(\mathrm{SR})=\mathrm{EC}_{50}(\mathrm{th}) / \mathrm{EC}_{50}(\mathrm{ob})
\end{aligned}
$$

$\mathrm{EC}_{50}(\mathrm{ob})$ represents the actual $\mathrm{EC}_{50}, \mathrm{EC}_{50}(\mathrm{th})$ represents the theoretical $\mathrm{EC}_{50}, \mathrm{~A}$ and $\mathrm{B}$ are single agents, and $\mathrm{a}$ and $\mathrm{b}$ are the mass ratios of the two in the mixture. $\mathrm{SR}=0.5-1.5$ is additive, $\mathrm{SR}<0.5$ is antagonistic and SR $>1.5$ is synergistic [30].

\subsection{Greenhouse Safety Assessment Experiment}

The cultivar of cotton used in this study was Lumian 28, Lumian 37 and Lumian 338. Using $6 \%$ fluopimomide, $6.15 \%$ fluopimomide and LNT as a seed coating agent. The dosage of the active ingredients used in the seed coating experiment was 4 dosages, including $1,1.5,2,2.5$ times the recommended dosage in the field. The specific dosage of the seed coating agent was: $6 \%$ fluopimomide seed coating agent $9.6,14.4,19.2,24.0 \mathrm{mg}$ a.i. $/ \mathrm{kg}$ seed and $6.15 \%$ fluopimomide lentinan seed coating agent $9.6,14.4,19.2,24.0 \mathrm{mg}$ a.i. $/ \mathrm{kg}$ seed. The treatment without chemicals was used as the blank control. A set of 5 replicates was performed per treatment. The effect of plant height, stem thickness and germination rate were evaluated.

The cotton seeds were surface sterilized in $1 \%(w / v) ~ N a O C l$ and $70 \%(v / v)$ ethanol for 3 min each and rinsed three times in sterile distilled water [31]. Seed germination assay and seedling growth assay were carried out according to Zhang et al. [32]. Germination assay: for each treatment, 4 replicates of 20 seeds were planted in sterilized sand (60-70 mesh, $20 \%$ moisture), and grown at $25 \pm 1{ }^{\circ} \mathrm{C}$ with a $14 \mathrm{~h}$ : $10 \mathrm{~h} \mathrm{light:dark}$ ratio (L:D) and $70 \pm 5 \%$ relative humidity. When the main root length of cotton exceeds the seed length or the bud length exceeds $1 / 2$ of the seed length, it could be regarded as seed germination. The haircutting bud rate was recorded and calculated at 3 days after germination. The germination rate was calculated according to the following formula:

Germination rate $(\%)=$ number of germinated seeds $/$ total number of species $\times 100 \%$

Seedling growth assay: triplicates of 25 seeds each were seeded in pots with sterilized nutrient soil ( $60 \%$ moisture). Plants were cultivated under the same conditions described above. Plant heights were recorded for 20 days after emergence. 


\subsection{Greenhouse Control Effect Experiments}

The germinated cotton seeds were transplanted to the greenhouse of Shandong Agricultural University. We measured the control effect of cotton damping-off disease caused by AG-4 at 7 days in the greenhouse experiment via the application of seed coating agent containing $6 \%$ fluopimomide, $6.15 \%$ fluopimomide and LNT, respectively. Pharmaceutical control azoxystrobin: clean water was used as a control. Each pot was then treated with $20 \mathrm{~mL}$ of the R. solani AG-4 suspension. A set of 5 replicates was performed per treatment. The classification standard was as described in Huang et al. [33].

\subsection{Field Trials}

Field tests were conducted in the cotton field of Wucheng village, Dezhou, Shandong, China $\left(37.08^{\circ} \mathrm{N}, 115.93^{\circ} \mathrm{E}\right)$ and Cotton research center, Shandong academy of agricultural sciences, Liaocheng, Shandong, China $\left(36.81^{\circ} \mathrm{N}, 115.70^{\circ} \mathrm{E}\right)$, two field trials were performed in 2020. The field is a serious damping-off region with years of continuous cotton cropping. The concentration of each treatment group was set as follows: $4.8,7.2,9.6 \mathrm{mg}$ a.i. $/ \mathrm{kg}$ seed. Pharmaceutical control azoxystrobin: clean water was used as a control. The experimental field for each treatment covered $30 \mathrm{~m}^{2}$. A random block arrangement was adopted between each cell, with three replications. The seeding of cotton in the two test sites was carried out by manual seeding. The row spacing was kept at about $80 \mathrm{~cm}$, and the ditching was used for direct seeding. The plant spacing was controlled at about $15 \mathrm{~cm} .1 \mathrm{~m}$ protection rows were reserved at both ends of each plot to ensure the distance between the plots did not affect each other. We investigated the incidence of cotton damping-off and its control effect each year on 14 May and 22 May.

\subsection{Spray and Irrigation Root Treatment}

After the cotton seedling emerged, spray at 50, 100 and $200 \mathrm{mg} \cdot \mathrm{L}^{-1} \mathrm{LNT}$ to irrigate the roots was carried out; water treatment was used as a control. Each treatment included 20 cotton seedlings. The incidence and index were recorded 7 days after the emergence. Calculate disease severity and control according to the description of Zhang et al. [5]. The pesticide concentration with the most obvious growth-promoting effect was selected for the late enzyme activity and real-time quantitative PCR test.

\subsection{Measurement of Defense Enzyme Activities}

For crude enzyme extraction, refer to Mahunu et al. [34]. Melatonin treatment groups of different concentrations were obtained, $0.5 \mathrm{~g}$ of seeds were germinated to the $2 \mathrm{nd}$, 4 th and 6th days, put in a mortar (mortar pre-cooled at $-20^{\circ} \mathrm{C}$ for $1 \mathrm{~h}$ ), added 1:9 to the pre-cooled phosphate buffer (PBS $\mathrm{Ph}=7.0$, containing $1 \%$ polyvinylpyrrolidone and $0.1 \%$ mercaptoethanol) and ground in an ice bath; the homogenate was poured into a centrifuge tube, and refrigerated and centrifuged at $1000 \mathrm{r} \cdot \mathrm{min}^{-1}$ for $20 \mathrm{~min}$, then stored at $4{ }^{\circ} \mathrm{C}$ until use.

The lentinan with the best concentration for inducing effect was selected to treat cotton plants and inoculated with the spore suspension of the test species 2 days later. To study the physiological mechanism of lentinan-induced cotton wilt disease, the experimental design was as follows: (A) clear water (CK); (B) inoculation of R. solani (CK-inoculation) without lentinan treatment; (C) treatment with LNT but not $R$. solani; (D) treatment with LNT and inoculated with $R$. solani. 1-7 days after inoculation with $R$. solani, the 3rd to 4 th unfolded leaves of cotton plants (without induced treatment) were used to determine the polyphenol oxidase SOD, PPO and POD activities.

\subsection{Malondialdehyde (MDA) Assay}

The content of malondialdehyde $\left(\mu \mathrm{mol} \mathrm{g}{ }^{-1}\right)$ was determined by the thiobarbituric acid method. Weigh $0.5 \mathrm{~g}$ of chopped cotton leaves in a mortar, added $1 \mathrm{~mL}$ mass fraction of $10 \%$ TCA and a small amount of quartz sand, and then added $4 \mathrm{~mL}$ TCA for further grinding. The homogenate was centrifuged at $4000 \mathrm{r}$ min for $10 \mathrm{~min}$, and the supernatant 
was the sample extract. A $2 \mathrm{~mL}$ pipette of centrifuged supernatant (control plus $2 \mathrm{~mL}$ of distilled water) was added to $2 \mathrm{~mL}$ of $\mathrm{tbA}$ solution with a mass fraction of $0.6 \%$, mixed well, and the mixture was reacted in a boiling water bath for $15 \mathrm{~min}$. After rapid cooling, it was centrifuged again. The supernatant was obtained and the extinction was measured at 450,532 and $600 \mathrm{~nm}$ wavelength. CMDA $\left(\mu \mathrm{mol} \mathrm{L}^{-1}\right)=6.45\left(\mathrm{~A}_{532}-\mathrm{A}_{600}\right)-0.56 \mathrm{~A}_{450}$, this yielded absolute MDA concentrations ( $\mu \mathrm{mol} \mathrm{g}{ }^{-1}$ R. solani) [35].

\subsection{RNA Extraction and Quantitative Real-Time PCR ( $q R T-P C R$ )}

Cotton leaf tissue exposed to $100 \mathrm{mg} \mathrm{L}^{-1}$ LNT was collected at 7 days after seedling emergence and stored at $-80^{\circ} \mathrm{C}$. RNA extraction was performed as described by Zhang et al. [9]. Draw a standard curve using a series of standards with known initial copy numbers to establish a linear relationship between the $\mathrm{Ct}$ value and the logarithm of the initial template amount. From the $\mathrm{Ct}$ value of the unknown sample, the initial copy number of the unknown sample can be calculated from the standard curve. This experiment uses the $2^{-\Delta \Delta \mathrm{Ct}}$ method commonly used in relative quantification, where $\Delta \Delta \mathrm{Ct}=(\mathrm{Ct}$ target gene- $\mathrm{Ct}$ internal reference) experimental group-( $\mathrm{Ct}$ target gene- $\mathrm{Ct}$ internal reference) control group. The detailed detection procedures were as follows: pre-denatured at $95^{\circ} \mathrm{C}$ for $3 \mathrm{~min}, 95^{\circ} \mathrm{C}$ denaturation for $10 \mathrm{~s}, 60^{\circ} \mathrm{C}$ annealing extension $30 \mathrm{~s}, 40$ cycles. The relative expression analysis was performed in triplicate. Specific primers were designed using the Primer Express software (Sandon Biotech, Shanghai, China) (Table 2).

Table 2. Multiple sets of real-time quantitative polymerase chain reaction primers for amplifying specific regions of genes.

\begin{tabular}{|c|c|}
\hline Genes & Sequence \\
\hline \multirow[b]{2}{*}{$4 C L$} & 5'-ATTCAAAAGGGAGATGCC-3' \\
\hline & $5^{\prime}$-GAGAAGGGCAAAGCAACA- $3^{\prime}$ \\
\hline \multirow{2}{*}{$\mathrm{C} 4 \mathrm{H} 1$} & 5'-CTTCACCATCATCTTTGCC-3' \\
\hline & 5'-CGAACTCAACTCCTTGGGT-3' \\
\hline \multirow{2}{*}{$P A L$} & 5'-TGGTGGCTGAGTTTAGGAAA-3' \\
\hline & 5'-TGAGTGAGGCAATGTGTGA-3' \\
\hline \multirow{2}{*}{ NPR1 } & 5'-CTGATGCTAGCTCATCAATGGC-3' \\
\hline & 5'-GGGACCTGAAAAACGAACGC-3' \\
\hline \multirow{2}{*}{ NPR2 } & 5'-TCGCACGTTGGATGTAGACC-3' \\
\hline & 5'-TCTCTATACACAACCTGTCCTTCG-3' \\
\hline \multirow[b]{2}{*}{ NPR3 } & 5'-ATCGACCGAGGAAGGTAAGG-3' \\
\hline & 5'-TTTTTTTTTTTTTTGATTTACACA-3' \\
\hline \multirow{2}{*}{ OPR } & 5'-TGCTGTTCATGCGAAAGGTGGA-3' \\
\hline & 5'-ATCGCCTCGGAGGTGAGAAGTC-3' \\
\hline \multirow[b]{2}{*}{ AOS } & 5'-AATGTTCGCAGTCGGCTGTCAG-3' \\
\hline & $5^{\prime}$-TGGACCTGGTGGCATGTTTGTT-3' \\
\hline
\end{tabular}

\subsection{Statistical Analyses}

Use SPSS software (v18, SPSS Inc., IBM Corp., Armonk, NY, USA) was used to calculate the inhibition rate $/ \%=($ control colony growth diameter-treated colony growth diameter)/control colony growth diameter $\times 100, \mathrm{EC}_{50}$ value and $95 \%$ confidence interval. Different letters $(\mathrm{abc})$ represent significant differences, $p<0.05$; ABC mean significant level $p<0.01$.

\section{Results}

\subsection{Types and Occurrence of Main Diseases in Main Cotton Planting Areas}

To investigate the occurrence of major diseases in the main cotton growing areas in Shandong, mainly in Dezhou, Liaocheng, Dongying, Binzhou, Heze and Jining, a cotton disease survey was conducted. The incidence of cotton seedling diseases in Shandong was $32.2-58.8 \%$, and the disease index was $16.2-38.2$, mainly including cotton damping-off, 
red rot, anthracnose and phytophthora blight. Among them, the occurrence of cotton damping-off was the most serious (Table 3).

Table 3. Disease incidence of cotton seeding.

\begin{tabular}{cccc}
\hline Prefecture & Incidence Rate (\%) & Disease Index & Main Diseases \\
\hline Dezhou & 50.8 & 28.3 & damping-off, anthracnose \\
Liaochneg & 49.6 & 29.3 & damping-off, red rot, anthracnose \\
Dongying & 58.8 & 38.2 & damping-off, red rot \\
Binzhou & 46.2 & 25.1 & damping-off, anthracnose \\
Heze & 56.0 & 34.9 & damping-off, red rot, anthracnose \\
Jining & 32.2 & 16.2 & damping-off, red rot, anthracnose \\
\hline
\end{tabular}

\subsection{In Vivo Experiments}

The results showed that the $\mathrm{EC}_{50}$ values of the inhibitory effects of fludioxonil and lentinan on $R$. solani AG-4 compared to that of the control were 0.031 (the lowest value) and 54.751 (the highest value) $\mathrm{mg} \mathrm{L}^{-1}$, respectively (Table 4). Meanwhile, the results indicated that the $\mathrm{EC}_{50}$ values of the inhibitory effects of fludioxonil and lentinan on $R$. solani LQ-M compared to that of the control were 0.042 (the lowest value) and 58.189 (the highest value) $\mathrm{mg} \mathrm{L}^{-1}$, respectively (Table 5). Then, the results indicated that the $\mathrm{EC}_{50}$ values of the inhibitory effects of fludioxonil and carbendazim on $R$. solani AG-2 compared to that of the control were 0.044 (the lowest value) and 34.153 (the highest value) $\mathrm{mg} \mathrm{L}^{-1}$, respectively (Table 6). The new pesticide fluopimomide, the $\mathrm{EC}_{50}$ values against AG-4, LQ-M and AG-2 were $0.388,0.457$ and $0.427 \mathrm{mg} \mathrm{L}^{-1}$, it had a good control effect on cotton $R$. solani. In addition, the $\mathrm{EC}_{50}$ value of LNT (a biological pesticide) against AG-4, LQ-M and AG-2, were $54.751,58.189$ and $30.870 \mathrm{mg} \mathrm{L}^{-1}$, respectively. Its virulence was low.

Table 4. Toxicity of fungicides to standard strain of Rhizoctonia solani AG-4.

\begin{tabular}{ccccc}
\hline Fungicide & Regression Equation & $\mathbf{R}^{\mathbf{2}}$ & $\mathbf{E C}_{\mathbf{5 0}}(\mathbf{m g} / \mathbf{L})^{\mathbf{1}}$ & $\mathbf{9 5 \%}$ Confidence Limits \\
\hline fludioxonil & $\mathrm{y}=1.693+1.119 \mathrm{x}$ & 0.986 & 0.031 & $0.017-0.052$ \\
pyraclostrobin & $\mathrm{y}=0.556+0.589 \mathrm{x}$ & 0.949 & 0.114 & $0.046-1.147$ \\
hexaconazole & $\mathrm{y}=0.492+0.662 \mathrm{x}$ & 0.956 & 0.181 & $0.085-1.336$ \\
fluopimomide & $\mathrm{y}=0.390+0.948 \mathrm{x}$ & 0.902 & 0.388 & $0.195-2.131$ \\
difenoconazole & $\mathrm{y}=-1.305+2.160 \mathrm{x}$ & 0.941 & 4.019 & $3.576-4.577$ \\
carbendazim & $\mathrm{y}=-2.757+1.927 \mathrm{x}$ & 0.973 & 26.968 & $24.910-29.351$ \\
lentinan & $\mathrm{y}=-2.919+1.679 \mathrm{x}$ & 0.945 & 54.751 & $48.192-63.353$ \\
\hline
\end{tabular}

${ }^{1} \mathrm{EC}_{50}$ (half maximal effective concentration) values are widely used to express the efficacy and sensitivity of plant pathogens to fungicides. The smaller the $\mathrm{EC}_{50}$ value, the more sensitive the pathogen is to the fungicide. The $\mathrm{EC}_{50}$ values of seven pesticides and their $95 \%$ relative confidence intervals (RCIs) were calculated with SPSS 18.0 software.

Table 5. Toxicity of fungicides to Rhizoctonia solani Linqing isolate LQ-M.

\begin{tabular}{ccccc}
\hline Fungicide & Regression Equation & $\mathbf{R}^{\mathbf{2}}$ & $\mathbf{E C}_{\mathbf{5 0}}(\mathbf{m g} / \mathbf{L})^{\mathbf{1}}$ & $\mathbf{~ 9 5 \% ~ C o n f i d e n c e ~ L i m i t s ~}^{\text {95 }}$ \\
\hline fludioxonil & $\mathrm{y}=2.049+1.493 \mathrm{x}$ & 0.962 & 0.042 & $0.039-0.046$ \\
pyraclostrobin & $\mathrm{y}=0.762+0.964 \mathrm{x}$ & 0.987 & 0.162 & $0.137-0.195$ \\
hexaconazole & $\mathrm{y}=0.584+0.901 \mathrm{x}$ & 0.986 & 0.225 & $0.185-0.284$ \\
fluopimomide & $\mathrm{y}=0.366+1.077 \mathrm{x}$ & 0.973 & 0.457 & $0.392-0.544$ \\
difenoconazole & $\mathrm{y}=-1.422+2.004 \mathrm{x}$ & 0.934 & 5.123 & $4.372-6.166$ \\
carbendazim & $\mathrm{y}=-2.698+1.808 \mathrm{x}$ & 0.960 & 31.070 & $27.270-36.048$ \\
lentinan & $\mathrm{y}=-2.980+1.689 \mathrm{x}$ & 0.950 & 58.189 & $52.044-65.923$ \\
\hline
\end{tabular}

${ }^{1} \mathrm{EC}_{50}$ (half maximal effective concentration) values are widely used to express the efficacy and sensitivity of plant pathogens to fungicides. The smaller the $\mathrm{EC}_{50}$ value, the more sensitive the pathogen is to the fungicide. The $\mathrm{EC}_{50}$ values of seven pesticides and their $95 \%$ relative confidence intervals (RCIs) were calculated with SPSS 18.0 software. 
Table 6. Toxicity of fungicides to standard strain Rhizoctonia solani AG-2.

\begin{tabular}{ccccc}
\hline Fungicide & Regression Equation & $\mathbf{R}^{\mathbf{2}}$ & $\mathbf{E C}_{\mathbf{5 0}}(\mathbf{m g} / \mathbf{L})^{\mathbf{1}}$ & $\mathbf{9 5 \%}$ Confidence Limits \\
\hline fludioxonil & $\mathrm{y}=2.493+1.842 \mathrm{x}$ & 0.903 & 0.044 & $0.037-0.053$ \\
pyraclostrobin & $\mathrm{y}=1.523+1.233 \mathrm{x}$ & 0.988 & 0.058 & $0.052-0.065$ \\
hexaconazole & $\mathrm{y}=0.646+0.944 \mathrm{x}$ & 0.978 & 0.207 & $0.177-0.248$ \\
fluopimomide & $\mathrm{y}=0.360+0.975 \mathrm{x}$ & 0.964 & 0.427 & $0.366-0.510$ \\
difenoconazole & $\mathrm{y}=-0.031+0.423 \mathrm{x}$ & 0.960 & 1.186 & $0.860-1.564$ \\
lentinan & $\mathrm{y}=-0.953+0.640 \mathrm{x}$ & 0.911 & 30.870 & $25.635-37.830$ \\
carbendazim & $\mathrm{y}=-1.618+1.055 \mathrm{x}$ & 0.955 & 34.153 & $30.177-39.090$ \\
\hline
\end{tabular}

${ }^{1} \mathrm{EC}_{50}$ (half maximal effective concentration) values are widely used to express the efficacy and sensitivity of plant pathogens to fungicides. The smaller the $\mathrm{EC}_{50}$ value, the more sensitive the pathogen is to the fungicide. The $\mathrm{EC}_{50}$ values of seven pesticides and their $95 \%$ relative confidence intervals (RCIs) were calculated with SPSS 18.0 software.

\subsection{Synergistic Effect of Fluopimomide and Lentinan}

It can be seen from Table 7 that all the mixing ratios of fluopimomide and lentinan showed an increasing effect, and the synergic ratio was the largest when the ratio of lentinan:fluopimomide was 1:40, which was 1.228 , so we chose $1: 40$ as a ratio of fluopimomide and lentinan seed coating agent for the subsequent seed coating test.

Table 7. Fungitoxicity and synergism of the mixture of fluopimomide and lentinan.

\begin{tabular}{ccccccc}
\hline Lentinan: Fluopimomide & Regression Equation (y=) & $\mathbf{E C}_{\mathbf{5 0}}(\mathbf{o b})$ & $\mathbf{E C}_{\mathbf{5 0}}($ th) & $\mathbf{9 5 \%}$ Confidence Limits & $\mathbf{R}^{\mathbf{2}}$ & $\mathbf{S R}$ \\
\hline $1: 0$ & $1.689 x-2.980$ & 58.189 & - & $52.044-65.923$ & 0.950 & - \\
$0: 1$ & $1.077 x+0.366$ & 0.457 & - & $0.392-0.544$ & 0.973 & - \\
$1: 10$ & $0.392+1.399 x$ & 0.525 & 0.502 & $0.477-0.578$ & 0.988 & 0.956 \\
$1: 20$ & $0.419+1.371 x$ & 0.495 & 0.480 & $0.448-0.546$ & 0.989 & 0.970 \\
$1: 30$ & $0.434+1.215 x$ & 0.440 & 0.472 & $0.393-0.491$ & 0.984 & 1.073 \\
$1: 40$ & $0.445+1.063 x$ & 0.381 & 0.468 & $0.334-0.432$ & 0.983 & 1.228 \\
$1: 50$ & $0.456+1.230 x$ & 0.426 & 0.466 & $0.381-0.474$ & 0.980 & 1.094 \\
\hline
\end{tabular}

$\mathrm{EC}_{50}(\mathrm{ob})$ represents the actual $\mathrm{EC}_{50}, \mathrm{EC}_{50}(\mathrm{th})$ represents the theoretical $\mathrm{EC}_{50}, \mathrm{~A}$ and $\mathrm{B}$ are single agents, and $\mathrm{a}$ and $b$ are the mass ratios of the two in the mixture. $S R=0.5-1.5$ is additive, $\mathrm{SR}<0.5$ is antagonistic and $\mathrm{SR}>1.5$ is synergistic. The $\mathrm{EC}_{50}$ values of seven pesticides and their $95 \%$ relative confidence intervals (RCIs) were calculated with SPSS 18.0 software.

\subsection{Safety Evaluation of Seed Coating Agent on Cotton}

Table 8 shows the effects of four treatments on cotton germination. Among the results about cotton strain Lumian 28, final germination rate of $6 \%$ fluopimomide at concentration of $14.4 \mathrm{mg} / \mathrm{kg}$ was $90.00 \%$ (the highest value), which was slightly higher than CK; Among the results about cotton strain Lumian 38, final germination rate of these treatments was 93.75\% (the highest value), which was slightly lower than CK; Among the results regarding cotton strain Lumian 338, final germination rate of $6.15 \%$ fluopimomide and LNT at concentration of $19.2 \mathrm{mg} / \mathrm{kg}$ was $93.75 \%$ (the highest value), which was slightly higher than CK. Overall, the results of each treatment showed no significant difference with CK in the statistics field. These results indicated that the cotton germination rate was not affected with test conditions. As with Table 9, it shows the effects of these treatments on plant height and stem thickness. The results of each treatment showed no significant difference with CK in the statistics field. These results indicated that cotton height and stem thickness were not affected by test conditions. Both seed coating agents were safer for cotton germination and seedling growth.

\subsection{Greenhouse Experiment}

Table 10 showed that two treatments had a certain control effect on cotton damping-off disease. The control effect of $6 \%$ fluopimomide at a concentration of $9.6 \mathrm{mg} / \mathrm{kg}$ was $90.37 \%$, which was 1.46 fold of the value of $6 \%$ fluopimomide at concentration of $4.8 \mathrm{mg} / \mathrm{kg}$; The control effect of $6.15 \%$ fluopimomide and LNT at a concentration of $9.6 \mathrm{mg} / \mathrm{kg}$ was $88.52 \%$, 
which was 1.47 fold of the value of $6.15 \%$ fluopimomide and LNT at a concentration of $4.8 \mathrm{mg} / \mathrm{kg}$; These results indicated that control effects on cotton damping-off disease gradually increased with concentrations of the respective treatment. The results showed that control effects on cotton damping-off disease gradually increased with concentrations of the respective treatment. The control effect of the mixture of fluopimomide and LNT under the same active ingredient was not much different from that of fluopimomide single agent. It indicates that biopesticide LNT could reduce the dose of chemical pesticides.

Table 8. Effect of fungicides on cotton seed germination.

\begin{tabular}{|c|c|c|c|c|c|c|c|}
\hline \multirow[b]{2}{*}{ Fungicides } & \multirow[b]{2}{*}{$\begin{array}{l}\text { Dosage } \\
\text { (mg/kg } \\
\text { Seeds) }\end{array}$} & \multicolumn{2}{|c|}{ Lumian 28} & \multicolumn{2}{|c|}{ Lumian 38} & \multicolumn{2}{|c|}{ Lumian 338} \\
\hline & & $\begin{array}{l}\text { CK Complete } \\
\text { Germination } \\
\text { Rate } \%\end{array}$ & $\begin{array}{l}\text { 3d after the } \\
\text { CK Complete } \\
\text { Germination } \\
\%\end{array}$ & $\begin{array}{c}\text { Complete } \\
\text { Germination } \\
\text { Rate } \%\end{array}$ & $\begin{array}{c}\text { 3d after the } \\
\text { CK Complete } \\
\text { Germination } \\
\%\end{array}$ & $\begin{array}{l}\text { CK Complete } \\
\text { Germination } \\
\text { Rate } \%\end{array}$ & $\begin{array}{c}\text { 3d after the } \\
\text { CK Complete } \\
\text { Germination } \\
\%\end{array}$ \\
\hline \multirow{4}{*}{$\begin{array}{l}6 \% \text { fluopimomide } \\
\text { seed coating }\end{array}$} & 9.6 & $88.75 \pm 1.25 \mathrm{a}$ & $88.75 \pm 1.25 \mathrm{a}$ & $91.25 \pm 2.39 \mathrm{a}$ & $92.50 \pm 1.44 \mathrm{a}$ & $88.75 \pm 1.25 \mathrm{a}$ & $88.75 \pm 1.25 \mathrm{a}$ \\
\hline & 14.4 & $90.00 \pm 2.04 \mathrm{a}$ & $90.00 \pm 2.04 \mathrm{a}$ & $92.50 \pm 2.50 \mathrm{a}$ & $93.75 \pm 2.39 \mathrm{a}$ & $91.25 \pm 1.25 \mathrm{a}$ & $91.25 \pm 1.25 \mathrm{a}$ \\
\hline & 19.2 & $85.00 \pm 2.04 \mathrm{a}$ & $85.00 \pm 2.04 \mathrm{a}$ & $93.75 \pm 2.39 \mathrm{a}$ & $93.75 \pm 2.39 \mathrm{a}$ & $92.50 \pm 1.44 \mathrm{a}$ & $92.50 \pm 1.44 \mathrm{a}$ \\
\hline & 24.0 & $83.75 \pm 3.15 \mathrm{a}$ & $83.75 \pm 3.15 \mathrm{a}$ & $88.75 \pm 1.25 \mathrm{a}$ & $91.25 \pm 1.25 \mathrm{a}$ & $87.50 \pm 1.44 \mathrm{a}$ & $87.50 \pm 1.44 \mathrm{a}$ \\
\hline \multirow{4}{*}{$\begin{array}{l}6.15 \% \\
\text { fluopimomide-lentinan } \\
\text { seed coating }\end{array}$} & 9.6 & $87.50 \pm 1.44 \mathrm{a}$ & $87.50 \pm 1.44 \mathrm{a}$ & $92.50 \pm 2.50 \mathrm{a}$ & $92.50 \pm 2.50 \mathrm{a}$ & $92.50 \pm 1.44 \mathrm{a}$ & $92.50 \pm 1.44 \mathrm{a}$ \\
\hline & 14.4 & $88.75 \pm 1.25 \mathrm{a}$ & $88.75 \pm 1.25 \mathrm{a}$ & $90.00 \pm 2.04 \mathrm{a}$ & $91.25 \pm 2.50 \mathrm{a}$ & $92.50 \pm 2.50 \mathrm{a}$ & $92.50 \pm 2.50 \mathrm{a}$ \\
\hline & 19.2 & $86.25 \pm 3.75 \mathrm{a}$ & $86.25 \pm 3.75 \mathrm{a}$ & $93.75 \pm 2.39 \mathrm{a}$ & $93.75 \pm 2.39 \mathrm{a}$ & $93.75 \pm 2.39 \mathrm{a}$ & $93.75 \pm 2.39 \mathrm{a}$ \\
\hline & 24.0 & $85.00 \pm 2.04 \mathrm{a}$ & $85.00 \pm 2.04 \mathrm{a}$ & $88.75 \pm 2.39 \mathrm{a}$ & $91.25 \pm 2.39 \mathrm{a}$ & $88.75 \pm 1.25 \mathrm{a}$ & $88.75 \pm 1.25 \mathrm{a}$ \\
\hline CK & - & $88.75 \pm 2.39 \mathrm{a}$ & $88.75 \pm 2.39 \mathrm{a}$ & $96.25 \pm 2.39 \mathrm{a}$ & $96.25 \pm 2.39 \mathrm{a}$ & $90.00 \pm 2.04 \mathrm{a}$ & $90.00 \pm 2.04 \mathrm{a}$ \\
\hline
\end{tabular}

The value (quantity, mean \pm s.e.) were analyzed with ANOVA. Different letters indicate significant differences by Duncan's multiple range tests $(p<0.05)$ and they only apply to columns.

Table 9. Effect of $6 \%$ fluopimomide seed coating agent on plant height and stem diameter of cotton.

\begin{tabular}{|c|c|c|c|c|c|c|c|}
\hline \multirow[b]{2}{*}{ Fungicides } & \multirow{2}{*}{$\begin{array}{l}\text { Dosage } \\
\text { (mg/kg } \\
\text { Seeds) }\end{array}$} & \multicolumn{2}{|c|}{ Lumian 28} & \multicolumn{2}{|c|}{ Lumian 38} & \multicolumn{2}{|c|}{ Lumian 338} \\
\hline & & $\begin{array}{c}\text { Average Plant } \\
\text { Height }\end{array}$ & $\begin{array}{c}\text { Average Stem } \\
\text { Diameter }\end{array}$ & $\begin{array}{c}\text { Average Plant } \\
\text { Height }\end{array}$ & $\begin{array}{l}\text { Average Stem } \\
\text { Diameter }\end{array}$ & $\begin{array}{c}\text { Average Plant } \\
\text { Height }\end{array}$ & $\begin{array}{l}\text { Average Stem } \\
\text { Diameter }\end{array}$ \\
\hline \multirow{4}{*}{$\begin{array}{l}6 \% \text { fluopimomide seed } \\
\text { coating }\end{array}$} & 96 & $7.69 \pm 0.27 a$ & $1.66 \pm 0.10 \mathrm{a}$ & $6.60 \pm 0.15 a$ & $1.51 \pm 0.14 \mathrm{abc}$ & $7.49 \pm 0.12 \mathrm{ab}$ & $1.61 \pm 0.14 \mathrm{a}$ \\
\hline & 144 & $7.65 \pm 0.18 \mathrm{a}$ & $1.61 \pm 0.09 \mathrm{a}$ & $6.49 \pm 0.18 \mathrm{a}$ & $1.55 \pm 0.13 \mathrm{abc}$ & $7.61 \pm 0.12 \mathrm{ab}$ & $1.76 \pm 0.08 \mathrm{a}$ \\
\hline & 192 & $7.50 \pm 0.12 \mathrm{a}$ & $1.86 \pm 0.10 \mathrm{a}$ & $6.56 \pm 0.27 \mathrm{a}$ & $1.62 \pm 0.13 \mathrm{abc}$ & $7.48 \pm 0.12 \mathrm{ab}$ & $1.62 \pm 0.10 \mathrm{a}$ \\
\hline & 240 & $7.55 \pm 0.15 a$ & $1.75 \pm 0.14 \mathrm{a}$ & $6.45 \pm 0.14 \mathrm{a}$ & $1.46 \pm 0.10 \mathrm{abc}$ & $7.57 \pm 0.16 \mathrm{ab}$ & $1.86 \pm 0.11 \mathrm{a}$ \\
\hline \multirow{4}{*}{$\begin{array}{l}6.15 \% \\
\text { fluopimomide·lentinan } \\
\text { seed coating }\end{array}$} & 96 & $7.56 \pm 0.25 a$ & $1.66 \pm 0.11 \mathrm{a}$ & $6.49 \pm 0.19 a$ & $1.51 \pm 0.13 \mathrm{abc}$ & $7.60 \pm 0.16 \mathrm{ab}$ & $1.56 \pm 0.14 \mathrm{a}$ \\
\hline & 144 & $7.58 \pm 0.25 \mathrm{a}$ & $1.74 \pm 0.16 \mathrm{a}$ & $6.49 \pm 0.30 \mathrm{a}$ & $1.60 \pm 0.09 \mathrm{abc}$ & $7.47 \pm 0.11 \mathrm{ab}$ & $1.74 \pm 0.15 \mathrm{a}$ \\
\hline & 192 & $7.61 \pm 0.19 \mathrm{a}$ & $1.74 \pm 0.12 \mathrm{a}$ & $6.49 \pm 0.14 \mathrm{a}$ & $1.73 \pm 0.08 \mathrm{a}$ & $7.48 \pm 0.22 \mathrm{ab}$ & $1.80 \pm 0.15 \mathrm{a}$ \\
\hline & 240 & $7.55 \pm 0.21 \mathrm{a}$ & $1.73 \pm 0.06 \mathrm{a}$ & $6.44 \pm 0.21 \mathrm{a}$ & $1.48 \pm 0.10 \mathrm{abc}$ & $7.45 \pm 0.12 \mathrm{ab}$ & $1.73 \pm 0.12 \mathrm{a}$ \\
\hline CK & - & $7.59 \pm 0.19 \mathrm{a}$ & $1.66 \pm 0.15 \mathrm{a}$ & $6.49 \pm 0.20 \mathrm{a}$ & $1.67 \pm 0.08 \mathrm{ab}$ & $7.62 \pm 0.17 \mathrm{ab}$ & $1.73 \pm 0.12 \mathrm{a}$ \\
\hline
\end{tabular}

The value (quantity, mean \pm s.e.) were analyzed with ANOVA. Different letters indicate significant differences by Duncan's multiple range tests $(p<0.05)$ and they only apply to columns.

Table 10. Control effect of seed coating agent on cotton damping-off in pot.

\begin{tabular}{ccccc}
\hline Fungicides & Dosage (mg/kg Seeds) & Disease Index & Control Effect (\%) & Significantly Different \\
\hline \multirow{2}{*}{ 6\% fluopimomide seed } & 4.8 & 18.39 & $61.85 \pm 4.96$ & $\mathrm{dC}$ \\
coating & 7.2 & 10.89 & $77.41 \pm 2.80$ & $\mathrm{cB}$ \\
6.15\% & 9.6 & 4.64 & $90.37 \pm 1.96$ & $\mathrm{aA}$ \\
fluopimomide·lentinan & 4.8 & 19.11 & $60.37 \pm 3.80$ & $\mathrm{dC}$ \\
seed coating & 7.2 & 11.43 & $76.30 \pm 2.01$ & $\mathrm{cB}$ \\
$10 \%$ azoxystrobin FS & 9.6 & 5.54 & $89.52 \pm 1.64$ & $\mathrm{abA}$ \\
CK & 50 & 5.17 & - & $\mathrm{abA}$ \\
\end{tabular}

The value (quantity, mean \pm s.e.) were analyzed with ANOVA. Different letters indicate significant differences by Duncan's multiple range tests (Different letters (abcd) represent significant differences, $p<0.05$; ABC mean significant level $p<0.01$.) and they only apply to columns.

\subsection{Field Trials}

We investigated cotton seedling diseases in the field of Linqing $\left(36.81^{\circ} \mathrm{N}, 115.70^{\circ} \mathrm{E}\right)$, Wucheng $\left(37.08^{\circ} \mathrm{N}, 115.93^{\circ} \mathrm{E}\right)$ and Lijin $\left(37.50^{\circ} \mathrm{N}, 118.26^{\circ} \mathrm{E}\right)$, Shandong, China (Table 11). 
In these three places, the disease at the seedling stage had been weakened year by year, which may have a combined effect on the disease at the seedling stage when pesticides control other plant diseases.

Table 11. Investigation results of seedling diseases in three regions.

\begin{tabular}{ccccccc}
\hline Time & \multicolumn{2}{c}{ Linqing } & \multicolumn{2}{c}{ Wucheng } & \multicolumn{2}{c}{ Lijin } \\
& $\begin{array}{c}\text { Diseased Plant } \\
\text { Rate (\%) }\end{array}$ & Disease Index & $\begin{array}{c}\text { Diseased Plant } \\
\text { Rate (\%) }\end{array}$ & Disease Index & $\begin{array}{c}\text { Diseased Plant } \\
\text { Rate (\%) }\end{array}$ & Disease Index \\
\hline 2015 & 38.20 & 19.50 & 37.20 & 19.25 & 38.40 & 19.20 \\
2016 & 21.60 & 12.50 & 20.00 & 10.70 & 24.00 & 12.60 \\
2017 & 22.00 & 11.30 & 27.20 & 13.25 & 20.80 & 11.20 \\
\hline
\end{tabular}

As shown in Tables 12 and 13, the results of the field test (wucheng) of seed coating agents showed that cotton seeds treated with two seed coating agents had better control effects on cotton damping-off, $6 \%$ fluopimomide seed coating agent and $6.15 \%$ fluopimomide and LNT seed coating agent was $76.16 \%$ and $72.57 \%$ at $4.8 \mathrm{mg} / \mathrm{kg}$ seed; the control effect was $86.92 \%$ and $84.60 \%$ at $7.2 \mathrm{mg} / \mathrm{kg}$ seed; the control effect was $93.04 \%$ and $90.08 \%$ at $9.6 \mathrm{mg} / \mathrm{kg}$ seed. The results of the field trial of seed coating agents (Linqing) showed that the control effects of the two seed coating agents $6 \%$ fluopimomide seed coating agent and $6.15 \%$ fluopimomide and LNT seed coating agent at $4.8 \mathrm{mg} / \mathrm{kg}$ seeds were $74.11 \%$ and $70.57 \%$ The control effect was $80.67 \%$ and $79.08 \%$ at $7.2 \mathrm{mg} / \mathrm{kg}$ seed; the control effect was $92.02 \%$ and $90.78 \%$ at $9.6 \mathrm{mg} / \mathrm{kg}$ seed.

Table 12. Field control effect of seed coating agent on cotton damping-off (Wucheng).

\begin{tabular}{ccccc}
\hline Fungicides & Dosage (mg/kg Seeds) & Disease Index & Control Effect (\%) & Significantly Different \\
\hline 6\% fluopimomide seed & 4.8 & 8.07 & $76.16 \pm 1.21$ & $\mathrm{de}$ \\
coating & 7.2 & 4.43 & $86.92 \pm 1.56$ & $\mathrm{bc}$ \\
6.15\% & 9.6 & 2.57 & $93.04 \pm 1.76$ & $\mathrm{a}$ \\
fluopimomide·lentinan & 4.8 & 9.29 & $72.57 \pm 2.02$ & $\mathrm{e}$ \\
seed coating & 7.2 & 5.21 & $84.60 \pm 1.31$ & $\mathrm{cde}$ \\
10\% azoxystrobin FS & 9.6 & 3.36 & $80.08 \pm 1.11$ & $\mathrm{ab}$ \\
CK & 50 & 5.29 & -2.30 & $\mathrm{cde}$ \\
\hline
\end{tabular}

The value (quantity, mean \pm s.e.) were analyzed with ANOVA. Different letters indicate significant differences by Duncan's multiple range tests $(p<0.05)$ and they only apply to columns.

Table 13. Field control effect of seed coating agent on cotton damping-off (Linqing).

\begin{tabular}{ccccc}
\hline Fungicides & Dosage (mg/kg Seeds) & Disease Index & Control Effect (\%) & Significantly Different \\
\hline \multirow{2}{*}{ 6\% fluopimomide seed } & 4.8 & 10.43 & $74.11 \pm 2.43$ & $\mathrm{~cd}$ \\
coating & 7.2 & 7.79 & $80.67 \pm 1.06$ & $\mathrm{~b}$ \\
6.15\% & 9.6 & 3.21 & $92.02 \pm 1.60$ & $\mathrm{a}$ \\
fluopimomide·lentinan & 4.8 & 11.86 & $70.57 \pm 3.13$ & $\mathrm{de}$ \\
seed coating & 7.2 & 8.43 & $79.08 \pm 2.18$ & $\mathrm{bc}$ \\
10\% azoxystrobin FS & 9.6 & 3.71 & $90.78 \pm 1.23$ & $\mathrm{a}$ \\
CK & 50 & 7.93 & $80.32 \pm 2.08$ & $\mathrm{~d}$ \\
\hline
\end{tabular}

The value (quantity, mean \pm s.e.) were analyzed with ANOVA. Different letters indicate significant differences by Duncan's multiple range tests $(p<0.05)$ and they only apply to columns.

The results of field trials of seed coating agents (Linqing) showed that the control effect of $6 \%$ fluopimomide seed coating agent and $6.15 \%$ fluopimomide and LNT seed coating agent was equivalent at the same concentration, and there was no significant difference $(p<0.05)$. 


\subsection{Effect of LNT Treatment on Defense Enzyme Activities and MDA Contents of Cotton}

The activity of POD, SOD, PPO and the change of MDA content after treatment with different LNT concentrations can be seen in Figure 2. With the increase of the concentration of medication treatment, the activity of POD, SOD and PPO enzymes gradually decreased. The activities of the three enzymes reached the highest on the fourth and fifth days, and then showed a decreasing trend. The activities of POD, SOD and PPO within 7 days after LNT $100 \mathrm{mg} \cdot \mathrm{L}^{-1}$ and $200 \mathrm{mg} \cdot \mathrm{L}^{-1}$ treatments were significantly different from those of the CK treatment group. In addition, after treatment with LNT roots, the MDA content decreased significantly, and the decrease range increased with the increase of the dose.
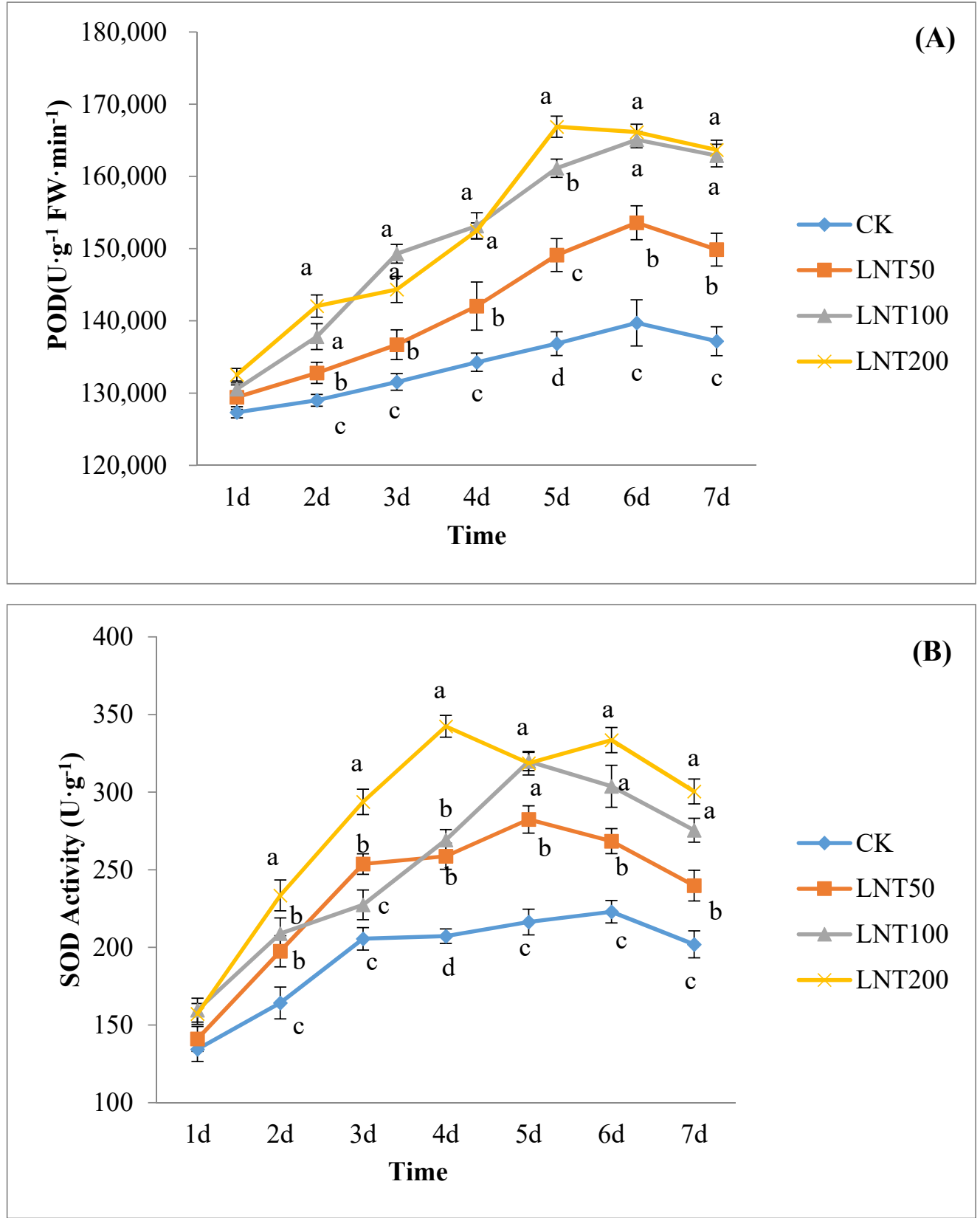

Figure 2. Cont. 

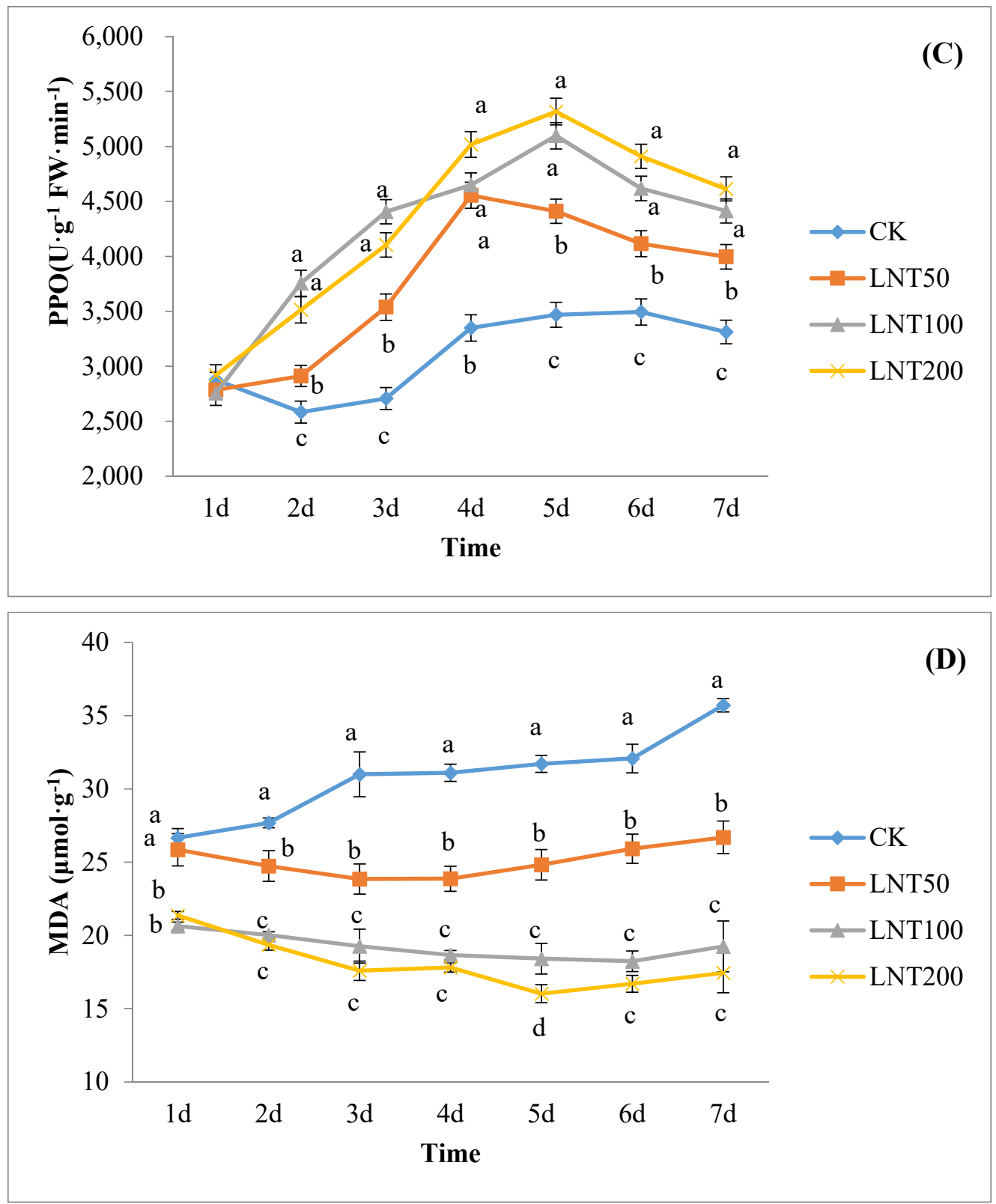

Figure 2. The effect of LNT treatment on the activities of defensive enzymes, such as (A): peroxidase (POD), (B): superoxide dismutase (SOD), (C): polyphenol oxidase (PPO) and (D): malondialdehyde (MDA) content. CK, LNT50, LNT100 and LNT200 indicate that cotton seedlings are treated with LNT containing $50 \mathrm{mg} \cdot \mathrm{L}^{-1}, 100 \mathrm{mg} \cdot \mathrm{L}^{-1}$ and $200 \mathrm{mg} \cdot \mathrm{L}^{-1}$, with water treatment as a control. Data (means $\pm \mathrm{SD}, n=3$ ) followed by different letters at the bar indicate significant differences $(p<0.05)$ among treatments.

\subsection{Effect of LNT Treatment on the Transcript Quantity of Cotton Disease Resistance-Related Genes}

We tested the gene expression levels on the leaves of cotton seedlings treated with $100 \mathrm{mg} \cdot \mathrm{L}^{-1} \mathrm{LNT}$. It can be seen from Figure 3 that NPR1, a key gene of the salicylic acid (SA) biosynthetic pathway, had been induced in large numbers. The expression levels of NPR3 gene and genes related to the phenylalanine metabolic pathway, such as PAL, C4H1 and $4 C L$, also increased significantly after treatment with LNT. No significant differences were found between the expression levels of other genes and the control group. 


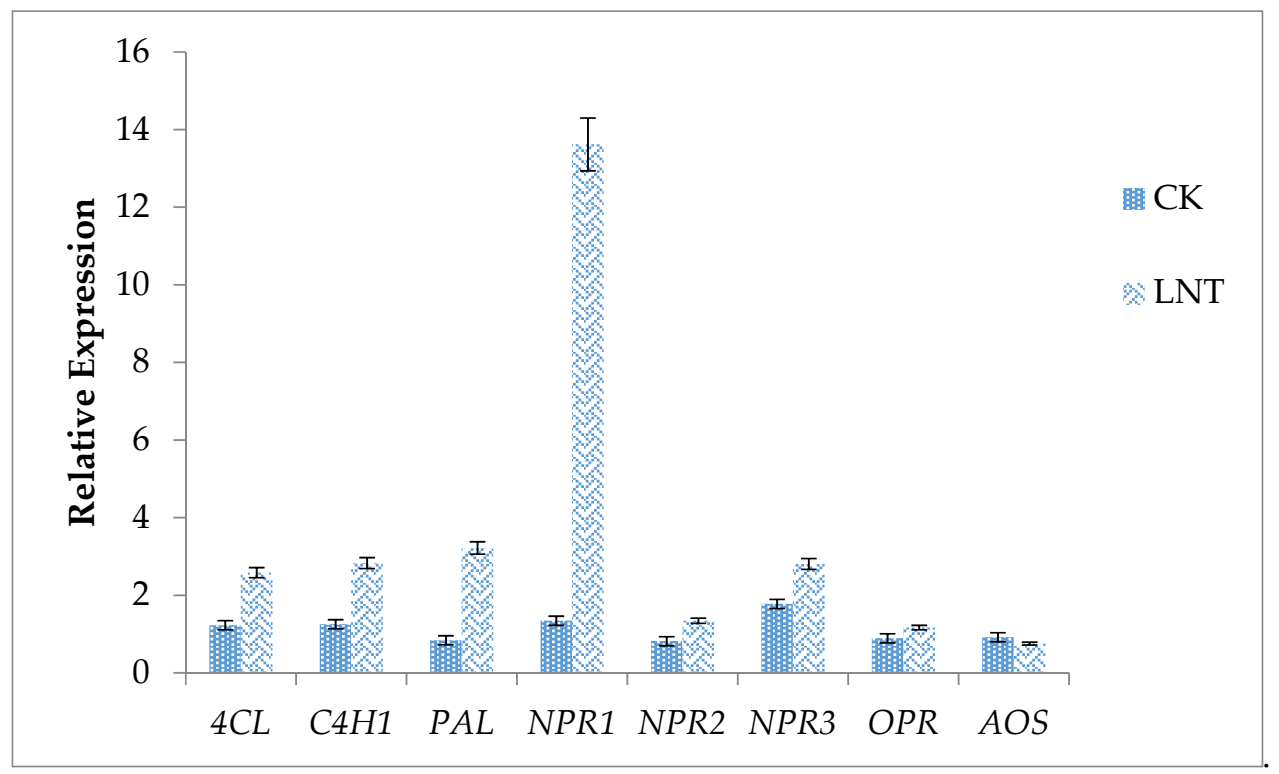

Figure 3. Effect of LNT treatment on the transcript quantity of cotton disease resistance-related genes. OPR: 12-oxo-phytodienoic acid reductase gene. 4CL: 4-coumarate gene. C4H1: Cinnamate-4hydroxylase gene. PAL, C4H1 and $4 C L$ are related genes of cotton phenylalanine metabolic pathway. NPR1, NPR2 and NPR3 are the genes of NPR and are the key factors in the salicylic acid (SA) signal pathway that can smoothly mediate the signal transduction pathway.

\section{Discussion}

Due to the continuous evolution of organisms, many have gradually evolved their own antioxidant defense systems [36]. Plant immune elicitors are generally divided into protein peptides, oligosaccharides, organic acids and inorganic compounds. Examples include, chitosan oligosaccharide (COS) obtained by hydrolysis of chitosan, which can be used as an effective inducer of plant immunity [37]; oligosaccharides can seriously reduce the severity of cucumber mosaic virus (CMV) [38]; kelp polysaccharides can induce tobacco resistance to carrot soft rot Erwinia [39], and also significantly increase expression levels of defense-related genes LOX and GST in grape leaf cells [40]; LNT can regulate plant growth, induce the activation of the plant defense response, enhance the plant's resistance against diseases, and thereby induce the plant's resistance to plant viruses and fungal diseases [41,42]. In addition, Ganoderma Lucidum polysaccharide can effectively control cotton fusarium wilt [9] and LNT can effectively control sharp eyespot of wheat [32].

For a long time, prolific plants have gradually formed a complete immune system [43]. At present, the use of chemical pesticides is still the primary measure to prevent cotton damping-off disease in actual agricultural production but has been found to cause environmental pollution [44] and increased resistance [45]. Plant immune elicitors are usually a very conservative substance, mainly including oligosaccharides, peptides, proteins, lipids and other types [46]. Researchers use plant immune inducers to control plant diseases and insect pests [47] because they can reduce the pollution of chemical pesticides [48], activate the plant's own resistance system and enhance the plant's resistance to pathogens. In this paper, LNT as a biological pesticide effectively controls cotton damping-off disease caused by $R$. solani and reduces the frequent use of chemical pesticides to achieve the purpose of protecting the environment. The scientific and rational use of biological pesticides, such as LNT, can reduce the use of chemical pesticides, which will not cause harm to natural enemies. In the process of use, biological pesticides are difficult to produce drug resistance, and promote the healthy development of modern agriculture. Most biological pesticides are low-toxic or slightly toxic, they are easy to decompose, will not cause pollution to agricultural products and can effectively guarantee the quality and safety of agricultural products. Fluopimomide is more effective in controlling plant diseases compared to fuopi- 
colide $[49,50]$. In vivo tests, the $\mathrm{EC}_{50}$ values of fluopimomide against $R$. solani were lower than fuopicolide. Meanwhile, as a new pesticide fluopimomide plays an important role in plant disease control and contribute to crop protection to some extent. Not only does it help with the scientific use of a new pesticide, but also controls plant diseases in actual crop protection by carrying out relevant research on fluopimomide.

Seed treatments will protect plant seedlings from pre-emergence damping off disease, and also ensure plants have a healthy root system among their growth and development period [51]. Salicylic acid (SA) has physiological adjustment functions [52], such as delaying senescence, inducing flowering, and heat production, and can also induce the synthesis of disease-related proteases (PRP) in plants, thereby increasing the disease resistance of plants.

Induced resistance is related to the enhancement of the activity of defense enzymes (such as POD, SOD and PPO) [53]. Studies have shown that polysaccharides can induce plant POD, PPO and increase other defensive enzyme activities [54]. POD is one of the key enzymes in the pathway of lignin synthesis. As a defense gene, POD can induce the biosynthetic pathway of SA, lignin and phytoalexin, activate SAR46, and promote cell-wall strengthening and pathogen suppression [55]. In addition, POD can catalyze the decomposition of $\mathrm{H}_{2} \mathrm{O}_{2}$ and the polymerization of lignin monomers [56]. Polyphenol oxidase (PPO) can promote the lignification of the plant cell walls to reduce the damage of pathogens to plants, changes in PPO activity being important physiological indicators of plant disease resistance [57]. PPO is formed by catalyzing the formation of a protective barrier between lignin and quinone compounds, protecting cells from pathogens and directly exerting anti-disease effects by forming quinone compounds [58]. Malondialdehyde (MDA) is one of the products of membrane lipid peroxidation, as an important indicator of membrane lipid peroxidation, reflecting the degree of cell membrane damage and the plant's response to stress conditions [59].

\section{Conclusions}

Plants are constantly faced with several pathogenic agents and controlling this diseasecausing agent is crucial in the sustainable production of crops. The use of harmful synthetic chemical agents in controlling pathogens poses significant harm to human health and the environment. To overcome this, the use of organic control agents, such as lentinan (LNT), has considerable potential. We observed that LNT improved cotton seed germination rate and seedling growth, and also induced the expression of some defense genes in plants, hence is a good immune elicitor. Seeds treated with LNT increased in PPO, POD, and SOD activity and reduced MDA content. Lentinan is suitable for mixing with other chemical agents to improve the control effect, enhance plant resistance and ultimately increase yield. A large amount of pesticide use may cause problems, such as increased production costs, excessive residues on agricultural products, crop phytotoxicity, and environmental pollution. As a class of biological pesticides, plant immune inducers are changing the thinking of plant diseases and insect pest control. The use of plant immune elicitors, such as LNT, will improve this situation to a certain extent. There is a need for further in-depth understanding of plant immune elicitors in the future.

Author Contributions: Conceptualization, H.W.; methodology, J.W. and H.W.; software, S.S.; formal analysis, S.S. and H.Y.; investigation, G.C., S.Y. and Y.Y.; data curation, S.S. and H.Y.; writing-original draft, S.S. and H.W.; writing-review and editing, H.W.; funding acquisition, H.W. All authors have read and agreed to the published version of the manuscript.

Funding: This research was supported by the National Science Foundation of China (32102259), the Major Science and Technology Innovation Project of Shandong Province (2019JZZY020608), and the Central Guidance of Local Science and Technology Development Special Foundation of Shandong Province (YDZX2021088).

Institutional Review Board Statement: Not applicable.

Informed Consent Statement: Not applicable. 
Data Availability Statement: The data that support the findings of this study are available from the corresponding authors upon reasonable request.

Conflicts of Interest: The authors declare that they have no known competing financial interests or personal relationships that could have appeared to influence the work reported in this paper.

\section{References}

1. Guo, Q.; Dong, W.; Li, S.; Lu, X.; Wang, P.; Zhang, X.; Wang, Y.; Ma, P. Fengycin produced by Bacillus subtilis NCD-2 plays a major role in biocontrol of cotton seedling damping-off disease. Microbiol. Res. 2014, 169, 533-540. [CrossRef] [PubMed]

2. Chen, Y.; Zhang, A.F.; Wang, W.X.; Zhang, Y.; Gao, T.C. Baseline sensitivity and efficacy of thifluzamide in Rhizoctonia solani. Ann. Appl. Biol. 2012, 161, 247-254. [CrossRef]

3. Mikhail, M.S.; Kamel, K.S.; Omar, M.R.; Asran, A.A.; Kasem, K.K. Current Rhizoctonia solani anastomosis groups in Egypt and their pathogenic relation to cotton seedlings. Afr. J. Microbiol. Res. 2010, 4, 386-395.

4. Selim, H.M.M.; Gomaa, N.M.; Essa, A.M.M. Application of endophytic bacteria for the biocontrol of Rhizoctonia solani (Cantharellales: Ceratobasidiaceae) damping-off disease in cotton seedlings. Biocontrol Sci. Technol. 2017, 27, 81-95. [CrossRef]

5. Zhang, M.; Cheng, S.T.; Wang, H.Y.; Wu, J.H.; Luo, Y.M.; Wang, Q.; Wang, F.X.; Xia, G.X. iTRAQ-based proteomic analysis of defence responses triggered by the necrotrophic pathogen Rhizoctonia solani in cotton. J. Proteom. 2017, 152, 226-235. [CrossRef] [PubMed]

6. González García, V.; Portal Onco, M.A.; Susan, R. Biology and systematics of the form genus Rhizoctonia. Span. J. Agric. Res. 2006, 4, 55-79. [CrossRef]

7. Carling, D.E.; Baird, R.E.; Gitaitis, R.D.; Brainard, K.A.; Kuninaga, S. Characterization of AG-13, a newly reported anastomosis group of Rhizoctonia solani. Phytopathology 2002, 92, 893-899. [CrossRef] [PubMed]

8. Jabaji-Hare, S.; Neate, S.M. Nonpathogenic binucleate rhizoctonia spp. and benzothiadiazole protect cotton seedlings against rhizoctonia damping-off and alternaria leaf spot in cotton. Phytopathology 2005, 95, 1030-1036. [CrossRef] [PubMed]

9. Zhang, Z.X.; Wang, H.Y.; Wang, K.Y.; Jiang, L.L.; Wang, D. Use of lentinan to control sharp eyespot of wheat, and the mechanism involved. J. Agric. Food. Chem. 2017, 65, 10891-10898. [CrossRef] [PubMed]

10. Zhang, G.Y.; Su, L.Q.; Cao, A.J.; Han, G.J.; Bie, Z.Y.; Zhang, J.; Li, X.L. Lentinan promotes the root of Brassica CampestrisL. Braz. Arch. Biol. Technol. 2015, 58, 333-336. [CrossRef]

11. Wang, Y.; Jin, H.Y.; Yu, J.D.; Qu, C.H.; Wang, Q.; Yang, S.; Ma, S.C.; Ni, J. Quality control and immunological activity of lentinan samples produced in china. Int. J. Biol. Macromol. 2020, 159, 129-136. [CrossRef] [PubMed]

12. Wang, K.P.; Wang, J.; Li, Q.; Zhang, Q.L.; You, R.X.; Cheng, Y.; Luo, L.; Zhang, Y. Structural differences and conformational characterization of five bioactive polysaccharides from Lentinus edodes. Food Res. Int. 2014, 62, 223-232. [CrossRef]

13. Miyagawa, A. Chemical synthesis of $\beta-(1,3)$-glucan oligosaccharide and its application. Trends Glycosci. Glycotechnol. 2018, 30, E117-E127. [CrossRef]

14. Zhang, L.; Zhang, X.; Zhou, Q.; Zhang, P.; Zhang, M.; Li, X. Triple helix of $\beta$-d-glucan from lentinus edodes in $0.5 \mathrm{~m}$ nacl aqueous solution characterized by light scattering. Polym. J. 2001, 33, 317-321. [CrossRef]

15. Trotel-Aziz, P.; Couderchet, M.; Vernet, G.; Aziz, A. Chitosan stim-ulates defense reactions in grapevine leaves and inhibits devel-opment of Botrytis cinerea. Eur. J. Plant Pathol. 2006, 114, 405-413. [CrossRef]

16. Ménard, R.; Alban, S.; de Ruffray, P.; Jamois, F.; Franz, G.; Fritig, B.; Yvin, J.; Kauffmann, S. $\beta-1,3$ glucan sul-fate, but not $\beta-1$, 3 glucan, induces the salicylic acid signalingpathway in tobacco and arabidopsis. Plant. Cell 2004, 16, 3020-3032. [CrossRef] [PubMed]

17. Okubara, P.A.; Dickman, M.B.; Blechl, A.E. Molecular and genetic aspects of controlling the soilborne necrotrophic pathogens Rhizoctonia and Pythium. Plant. Sci. 2014, 228, 61-70. [CrossRef]

18. Foley, R.C.; Kidd, B.N.; Hane, J.K.; Anderson, J.P.; Singh, K.B. Reactive oxygen species play a role in the infection of the necrotrophic fungi, Rhizoctonia solani in wheat. PLoS ONE 2016, 11, e0152548. [CrossRef] [PubMed]

19. Zhang, R.; Wang, H.; Xu, H.; Wang, J.; Wang, K. Uptake and transportation behavior of a new fungicidal agent LH-2010A in cucumber plants. J. Pestic. Sci. 2014, 39, 43-47. [CrossRef]

20. Toquin, V.; Barja, F.; Sirven, C.; Bffa, R. Fluopicolide, a new anti-oomycetes fungicide with a new mode of action inducing perturbation of a spectrin-like protein. In Modern Crop Protection Compounds; Krämer, W., Schirmer, U., Eds.; Wiley-VCH Verlag GmbH: Weinheim, Germany, 2007; pp. 675-682.

21. Li, X.; Liu, Y.; He, L.; Gao, Y.; Mu, W.; Zhang, P.; Li, B.; Liu, F. Fungicide formulations influence their control efficacy by mediating physicochemical properties of spray dilutions and their interaction with target leaves. J. Agric. Food Chem. 2020, 68, 1198-1206. [CrossRef]

22. Ji, X.; Li, J.; Meng, Z.; Li, N.; Dong, B.; Zhang, S.; Qiao, K. Fluopimomide effectively controls Meloidogyne incognita and shows a growth promotion effect in cucumber. J. Pest. Sci. 2020, 93, 1421-1430. [CrossRef]

23. He, P.J.; Cui, W.Y.; He, P.B.; Munir, S.; Li, X.Y.; Wu, Y.X.; Li, Y.M.; Asad, S.; He, P.F.; He, Y.Q. Bacillus amyloliquefaciens subsp. plantarum KC-1 inhibits Zantedeschia hybrida soft rot and promote plant growth. Biol. Control 2021, 154, 104500. [CrossRef] 
24. Cui, K.D.; Zhang, L.Y.; He, L.M.; Zhang, Z.Q.; Zhang, T.; Mu, W.; Lin, J.; Liu, F. Toxicological effects of the fungal volatile compound 1-octen-3-ol against the red flour beetle, Tribolium castaneum (Herbst). Ecotoxicol. Environ. Saf. 2021, $208,111597$. [CrossRef]

25. Cheng, X.; Ji, X.; Ge, Y.; Li, J.; Qi, W.; Qiao, K. Characterization of antagonistic bacillus methylotrophicus isolated from rhizosphere and its biocontrol effects on maize stalk rot. Phytopathology 2018, 109, 571-581. [CrossRef]

26. Dukare, A.S.; Paul, S.; Nambi, V.E.; Gupta, R.K.; Singh, R.; Sharma, K.; Vishwakarma, R.K. Exploitation of microbial antagonists for the control of postharvest diseases of fruits: A review. Crit. Rev. Food Sci. Nutr. 2019, 59, 1498-1513. [CrossRef] [PubMed]

27. Yang, H.H.; Wang, L.; Li, S.J.; Gao, X.B.; Wu, N.N.; Zhao, Y.F.; Sun, W.H. Control of postharvest grey spot rot of loquat fruit with Metschnikowia pulcherrima E1 and potential mechanisms of action. Biol. Control 2021, 152, 104406. [CrossRef]

28. Gao, T.; Bian, R.; Joseph, S.; Taherymoosavi, S.; Shi, J. Wheat straw vinegar: A more cost-effective solution than chemical fungicides for sustainable wheat plant protection. Sci. Total Environ. 2020, 725, 138359. [CrossRef] [PubMed]

29. Marín, A.; Cháfer, M.; Atarés, L.; Chiralt, A.; Torres, R.; Usall, J.; Teixidó, N. Effect of different coating-forming agents on the efficacy of the biocontrol agent Candida sake CPA-1 for control of Botrytis cinerea on grapes. Biol. Control 2016, 96, 108-119. [CrossRef]

30. Cui, W.; Du, K.Y.; Ling, Y.X.; Yang, C.J. Activity of eugenol derivatives against fusarium graminearum q1 strain and screening of isoeugenol mixtures. J. Plant Pathol. 2021, 103, 915-921. [CrossRef]

31. Liu, T.; Zhu, L.S.; Xie, H.; Wang, J.H.; Wang, J.; Sun, F.X.; Wang, F.H. Effects of the ionic liquid 1-octyl-3-methylimidazolium hexafluorophosphate on the growth of wheat seedlings. Environ. Sci. Pollut. Res. 2013, 21, 3936-3945. [CrossRef]

32. Zhang, Z.X.; Diao, H.L.; Wang, H.Y.; Wang, K.Y.; Zhao, M. Use of Ganoderma Lucidum polysaccharide to control cotton Fusarium wilt, and the mechanism involved. Pestic. Biochem. Phys. 2019, 158, 149-155. [CrossRef]

33. Huang, J.X.; Liang, X.M.; Zhang, J.J.; Yan, X.J.; Dong, Y.H.; Li, C.S.; Zhang, L.P.; Xu, Z.T.; Li, L.; Yuan, H.Z.; et al. Fungicidal activity of 12-propoxyimino-1,15-pentadecanlactam on selected crops. Crop Prot. 2009, 28, 947-951. [CrossRef]

34. Mahunu, G.K.; Zhang, H.; Yang, Q.; Zhang, X.; Li, D.; Zhou, Y. Improving the biocontrol efficacy of pichia caribbica with phytic acid against postharvest blue mold and natural decay in apples. Biol. Control 2016, 92, 172-180. [CrossRef]

35. Qiu, Z.B.; Guo, J.L.; Zhu, A.J.; Zhang, L.; Zhang, M. Exogenous jasmonic acid can enhance tolerance of wheat seedlings to salt stress. Ecotoxicol. Environ. Saf. 2014, 104, 202-208. [CrossRef] [PubMed]

36. Bagnoli, F.; Giannino, D.; Caparrini, S.; Camussi, A.; Mariotti, D.; Racchi, M.L. Molecular cloning, characterisation and expression of a manganese superoxide dismutase gene from peach (Prunus persica (L.) Batsch). Mol. Genet. Genom. 2002, 267, 321-328. [CrossRef]

37. Mattaveewong, T.; Wongkrasant, P.; Chanchai, S.; Pichyangkura, R.; Chatsudthipong, V.; Muanprasat, C. Chitosan oligosaccharide suppresses tumor progression in a mouse model of colitis-associated colorectal cancer through ampk activation and suppression of nf-kb and mtor signaling. Carbohyd. Polym. 2016, 145, 30-36. [CrossRef]

38. Li, J.; Meng, Z.; Li, N.; Bei Dong Ji, X.; Zhang, S.; Qiao, K. Evaluating a new non-fumigant nematicide fluopimomide for management of southern root-knot nematodes in tomato. Crop Prot. 2019, 129, 105040. [CrossRef]

39. Klarzynski, O.; Plesse, B.; Joubert, J.M.; Yvin, J.C.; Kopp, M.; Kloareg, B.; Fritig, B. Linear $\beta-1,3$ glucans are elicitors of defense responses in tobacco. Plant Physiol. 2000, 124, 1027-1038. [CrossRef]

40. Aziz, A.; Poinssot, B.; Daire, X.; Adrian, M.; Bezier, A.; Lambert, B.; Joubert, J.M.; Pugin, A. Laminarin elicits defense responses in grapevine and induces protection against Botrytis cinerea and Plasmopara viticola. Mol. Plant-Microbe Interact. 2003, 16, 1118-1128. [CrossRef]

41. Wang, J.; Wang, H.Y.; Xia, X.M.; Li, P.P.; Wang, K.Y. Synergistic effect of Lentinula edodes and Pichia membranefaciens on inhibition of Penicillium expansum infections. Postharvest Biol. Technol. 2013, 81, 7-12. [CrossRef]

42. Wang, J.; Wang, H.Y.; Xia, X.M.; Li, P.P.; Wang, K.Y. Inhibitory effect of sulfated lentinan and lentinan against Tobacco mosaic virus (TMV) in tobacco seedlings. Int. J. Biol. Macromol. 2013, 61, 264-269. [CrossRef]

43. Jones, J.D.G.; Dangl, J.L. The plant immune system. Nature 2006, 444, 323-329. [CrossRef] [PubMed]

44. Hussain, S.; Siddique, T.; Saleem, M.; Arshad, M.; Khalid, A. Impact of pesticides on soil microbial diversity, enzymes, and biochemical reactions. Adv. Agron. 2009, 102, 159-200.

45. Lang, J.J.; Hu, J.; Ran, W.; Xu, Y.C.; Shen, Q.R. Control of cotton Verticillium wilt and fungal diversity of rhizosphere soils by bio-organic fertilizer. Biol. Fertil. Soils 2012, 48, 191-203. [CrossRef]

46. Schwessinger, B.; Ronald, P.C. Plant innate immunity: Perception of conserved microbial signatures. Annu. Rev. Plant Biol. 2012, 63, 451-482. [CrossRef]

47. Qiu, D.W.; Dong, Y.J.; Zhang, Y.; Li, S.P.; Shi, F.C. Plant immunity inducer development and application. Mol. Plant-Microbe Interact. 2017, 30, 355-360.

48. Oliveira, M.D.M.; Varanda, C.M.R.; Félix, M.R.F. Induced resistance during the interaction pathogen $x$ plant and the use of resistance inducers. Phytochem. Lett. 2016, 15, 152-158. [CrossRef]

49. Ji, X.; Li, J.; Meng, Z.; Zhang, S.; Dongm, B.; Qiao, K. Synergistic efect of combined application of a new fungicide fluopimomide with a biocontrol agent Bacillus methylotrophicus TA-1 for management of gray mold in tomato. Plant Dis. 2019, 103, $1991-1997$. [CrossRef]

50. Zhang, H.; Zhai, M.; Wang, K.; Xu, H.; Tang, J.; Wang, H. Study on fungicidal activity and mode of action of a novel fungicidal agent, LH-2010A against Rhoizoctonia solani. Chin. J. Pestic. Sci. 2013, 15, 405-411. 
51. Ajayi-Oyetunde, O.O.; Bradley, C.A. Rhizoctonia solani: Taxonomy, population biology and management of rhizoctonia seedling disease of soybean. Plant Pathol. 2017, 67, 3-17. [CrossRef]

52. Vlot, A.C.; Dempsey, D.A.; Klessig, D.F. Salicylic Acid, a multifaceted hormone to combat disease. Annu. Rev. Phytopathol. 2009, 47, 177-206. [CrossRef] [PubMed]

53. Dietz, K.J.; Turkan, I.; Krieger-Liszkay, A. Redox- and reactive oxygen species-dependent signalling in and from the Photosynthesizing Chloroplast. Plant Physiol. 2016, 171, 1541-1550. [CrossRef] [PubMed]

54. Burkhanova, G.F.; Yarullina, L.G.; Maksimov, I.V. The control of wheat defense responses during infection with Bipolaris sorokiniana by chitooligo-saccharides. Russ. J. Plant Physiol. 2007, 54, 104-110. [CrossRef]

55. Franco, G. Systemic acquired resistance in crop protection: from nature to a chemical approach. J. Agric. Food Chem. 2003, 51, 4487-4503.

56. Shri, M.; Kumar, S.D.; Trivedi, P.K.; Mallick, S.; Misra, P.; Shukla, D.; Mishra, S.; Srivastava, S.; Tripathi, R.; Tuli, R. Effect of arsenic on growth, oxidative stress, and antioxidant system in rice seedlings. Ecotoxicol. Environ. Saf. 2009, 72, 1102-1110. [CrossRef] [PubMed]

57. Mishra, B.B.; Gautam, S.; Sharma, A. Purification and characterisation of polyphenol oxidase (PPO) from eggplant (Solanum melongena). Food. Chem. 2012, 134, 1855-1861. [CrossRef]

58. Zhao, L.; Dong, J.; Hu, Z.; Li, S.; Su, X.; Zhang, J.; Yin, Y.; Xu, T.; Zhang, Z.; Chen, H. Anti-TMV activity and functional mechanisms of two sesquiterpenoids isolated from tithonia diversifolia. Pestic. Biochem. Phys. 2017, 140, 24-29. [CrossRef]

59. Song, M.Z.; Fan, S.L.; Pang, C.Y.; Wei, H.L.; Yu, S.X. Genetic analysis of the antioxidant enzymes, methane dicarboxylic aldehyde (MDA) and chlorophyll content in leaves of the short season cotton (Gossypium hirsutum L.). Euphytica 2014, 198, 153-162. [CrossRef] 